\title{
Connecting classrooms in rural communities through interactive whiteboards
}

\author{
Jane Mitchell \\ Charles Sturt University \\ Jane Hunter \\ University of Western Sydney \\ Nicole Mockler \\ University of Newcastle
}

\begin{abstract}
This paper reports on the uses of interactive whiteboards in 'connected classrooms' in rural New South Wales, Australia. The research specifically focuses on the $\mathrm{e}^{2}$ program, a senior school initiative among five schools that seeks to extend the range of curriculum options available for students by connecting classrooms using video conference and interactive whiteboard technology. Teachers working in these environments have created specific sets of pedagogical practices. Through a series of focus group interviews and observations of classrooms, the research has sought to document core features of the teaching practice in the connected classroom environment. The research details the ways in which the interactive whiteboard provides a key visual focus for all lessons in the connected classroom; how the interactive whiteboard is used alongside a video conference screen; and reasons why teachers are committed to working with these technologies.
\end{abstract}

\section{The $\mathrm{e}^{2}$ program and the research aims}

This paper reports on the use of interactive whiteboards, desktop sharing and video conference technologies as a means of connecting school classrooms across sites in rural New South Wales (NSW), Australia. These technologies together form an integral part of the $\mathrm{e}^{2}$ (Extending Education) program. The paper focuses on the essential role of the interactive whiteboard in this education innovation. The $\mathrm{e}^{2}$ program is a collaboration between five schools in the Western Region of the NSW Department of Education and Training (NSW DET). The sites are: Anson St School, Blayney High School, The Canobolas Rural Technology High School, Molong Central School and Orange High School. The schools are located in one small regional city and two small rural towns. The rural towns (Blayney and Molong) are approximately 40 kilometres from the regional city (Orange).

The purpose of the $\mathrm{e}^{2}$ program is to extend student curriculum options in the senior school. This purpose is achieved through an agreement between the schools that enables teachers to work across school sites, and the sharing of technology, equipment and subject electives between the schools. A key concern in establishing the program was to ensure that students in all schools had access to a wide array of curriculum subjects in their final two years of school. In 2005 the schools agreed to align their structures and timetables so that seven Year 11 and 12 subjects could be taught across 
the school sites. In 200936 subjects were taught collaboratively by the participating schools. These subjects are delivered in two modes: the 'connected classroom' mode in which interactive whiteboard and video conference technology are used to create classes across sites; and the 'super Wednesday' mode in which students travel to one school site per week for intensive half day lessons.

The $\mathrm{e}^{2}$ program is a major school and classroom innovation. The purpose of the research reported in this paper is to document and analyse the core teaching practices developed and employed by teachers in the 'connected classroom' mode, with a particular focus on how teachers integrate interactive whiteboard and video conference technology in order to create one learning environment that spans two school sites. The 'connected classrooms' are designed so that the standard equipment they utilise is consistent across school sites. At the front of each classroom are two screens; one with an interactive whiteboard visible across sites and one for the video conference connection. Bridgit software is used to enable the display of common material on the interactive whiteboard.

The questions guiding the research are:

- What pedagogic strategies have teachers developed working in the $\mathrm{e}^{2}$ environment?

- How are interactive whiteboards and video conferencing facilities used to connect classrooms across school sites?

- How are these strategies different to the 'traditional' classroom?

- What are the enablers and constraints to teaching and learning in the $\mathrm{e}^{2}$ environment?

The research project was conceived and enacted as a participatory research endeavour between school teachers in the $\mathrm{e}^{2}$ program and a small group of university researchers. The team worked collaboratively to design the methods of data collection and analysis.

\section{Research and policy context}

In Australia, key education documents (Ministerial Council on Education, Training and Youth Affairs - MCEETYA, 2005, 2006, 2008; Muir, 2004) feature technology integration in teaching and learning. Other education guidelines, for example the Melbourne Declaration on Educational Goals for Young Australians (MCEETYA, 2008a) cite reasons for schools to give priority to student learning with technology (Goal 2). For some time the focus on technology in student learning has been a preoccupation of national jurisdictions, and the promise of a 'digital education revolution' in 2008 further positioned technology as a key political platform for effective learning for students in Australian schools.

The Australian Government's commitment in this area involves A $\$ 1.2$ billion over the five years from 2008 to 2012 to "turn every secondary school in Australia into a digital school" (MCEETYA, 2008b, p. 5). This includes funds to all teacher employers in Australia, with up to $\mathrm{A} \$ 11.25$ million being directed to ICT-related school based professional development for teachers as part of Federal government policy. Concurrent with this growth in national education interest and policy in the area of learning technologies, the education landscape in NSW was preparing itself for significant technology based activity, including research on pedagogy using information and communication technologies (ICT) with universities, school based projects using technology and the NSW Quality Teaching Framework (NSW DET, 2003), 
and expert led teacher professional learning in schools focused on pedagogy in classrooms using new media.

Research conducted by NSW DET in partnership with the University of Technology, Sydney, explored pedagogy using interactive whiteboards (Schuck \& Kearney, 2006). The study found that teachers saw the technology as relatively easy to use as it fitted quite naturally with their practice, and its highly visual nature matched the 'digital culture' of students. Findings from a technology teacher professional learning project in six schools entitled Engaging Pedagogy (NSW DET, 2007) led by NSW DET speculated about a 'fresh technology equation' of quality digital resources, an interactive whiteboard and collaborative tools. This tool set was designed to promote high levels of intellectual engagement through a quality learning environment where the pedagogy required particular technology tools and content integration (Hunter, 2007).

During this time Western Region of the NSW Department of Education and Training had commissioned an education consultant from the University of Glamorgan to conduct teacher professional learning in schools on the use of interactive whiteboard technology for teaching and learning. At the same time international findings on the use of the interactive whiteboard as a tool for learning in teaching pedagogy were emerging. Such studies showed students found learning more engaging when their teachers used this technology in the classroom (Green \& Hannon, 2007). Two years prior Higgins (2005) had concluded that an increase in student learning outcomes in numeracy in the short term occurred when interactive whiteboards were used by teachers in some British schools. Kennewell (2006) and Kennewell and Higgins (2007) suggested that teachers who used this technology wisely liked the way in which they could demonstrate ideas on a large clear screen that everyone in the classroom could see. Across some of the findings Hennessy, Deaney, Ruthven and Winterbottom (2007) noted a recurring question associated with the use of interactive whiteboard technology concerning the degree to which the whiteboard was used to simply 'tweak' existing practice, or whether it could provide greater opportunities for student interaction with other students and existing resources. At the same time the use of video conferencing as a tool for distance education was attracting research attention (Martin, 2005).

The $\mathrm{e}^{2}$ program began 'connecting classrooms' in 2007, and shortly afterwards in March of the same year, a state election commitment of $A \$ 158$ million was announced for NSW DET with the Connected Classrooms Program, to date the largest state treasury enhancement for an education technology program in Australian education history. A four year program, it involves increasing current bandwidth, various new Web 2.0 learning applications for teachers and students, and a 'connected classroom' for 2,200 school sites. This space includes an interactive whiteboard, laptop, and Bridgit desktop sharing software and video conference equipment including LCD screen, video cameras and microphones. In May 2010 more than 1500 'connected classrooms' were installed across NSW DET. The 'connected classrooms' serve an important distance education purpose in the $\mathrm{e}^{2}$ program, and more broadly in western NSW, because schools can be physically separated by large distances and because teachers and students can be located at different sites.

With respect to the application of educational technology, Deaney, Ruthven and Hennessy (2006), comment that "the rationales guiding such innovation remain largely speculative, while the policies framing it are often slender in substance and 
exploratory in tone" (p. 460). In making this critique they call for research that ascertains teachers' perceptions and practices associated with their use of the technology. The research undertaken in this paper has sought to do just this: to document the specific pedagogies that teachers have developed working in the $\mathrm{e}^{2}$ environment and to provide commentary on the value of such technology to create classrooms that extend student curriculum options in the senior years of school.

\section{Design and methods}

The study was conducted as research development partnership between the $\mathrm{e}^{2}$ schools and Charles Sturt University, a tertiary institution located in Western NSW. The partnership also consulted with experts from within NSW DET and other NSW universities to develop the research methods and to collect and analyse data.

A group of five teachers working in the 'connected classroom' environment were invited to participate in the study. The study took place over five months and involved:

1. A research workshop to develop a collaborative approach to conducting classroom research that would build knowledge across classroom contexts;

2. One focus group interview with teachers to document key features of the pedagogical strategies that they have developed and deployed in the 'connected classroom';

3. Observations of the 'connected classrooms' and the preparation of lesson and program vignettes;

4. One focus group interview with teachers to discuss the vignettes and to refine detail related to their pedagogy, plus extended individual interviews with two teachers;

5. One focus group interview with six students to discuss their learning in a 'connected classroom' environment.

The study was premised on the fact that the $\mathrm{e}^{2}$ leadership team and teachers working in the 'connected classrooms' had been responsible for developing the knowledge required to work in these environments primarily through a process of school-based professional learning activities, trial and error, collaboration with colleagues, and accessing expertise from outside the schools. Therefore the research sought to document teachers' knowledge and extract core practices that existed across classroom sites. Each phase of the study helped to build a detailed picture of the core practices associated with teaching in a 'connected classroom' environment. Curriculum areas represented in the observations and focus group discussions included: Physics; Chemistry; Geography; Legal Studies and Hospitality. All teachers working in the 'connected classroom' environment were experienced or senior teachers. Typically these teachers chose to teach in a 'connected classroom' because of a commitment to their curriculum area and to ensure that it remained a study option for students in Year 11 and 12 across the schools in the $\mathrm{e}^{2}$ program.

The observations were conducted by two researchers, one member of the university team and one member of the $\mathrm{e}^{2}$ team. The observations took place in both the classrooms in which the teacher was physically located, as well as the 'receiving' classrooms (i.e. those without a teacher physically present and connected by video conference and interactive whiteboard). Teachers were asked to teach their regular 
lessons and to not divert from their planning and sequencing because of the observation. Six 45 minute lessons were observed in total. After the observations the two observers exchanged notes in order to build a detailed picture of practice. The observational notes were then written into what we have termed a lesson vignette. Each vignette was presented to the teacher whose lesson was observed so that they could check detail and add any other comments. The vignettes were presented to all teachers at the second focus group interview. Teachers read the vignettes and then worked as a team to identify common practices associated with the use of interactive whiteboard and video conference technology. The final focus group interview provided an opportunity for the group to check observational findings, to verify the vignettes, and to identify common and distinctive practices developed in these environments.

\section{Data analysis}

One observational school vignette has been included in this paper to present a picture of a lesson and the nature of the observational data. The vignette demonstrates the focus, flow and structure of a lesson; the material features of the 'connected classroom' including desks, chairs, video cameras, interactive whiteboard and LCD screen; their human features including the positions of students and teachers in the classrooms. The observations conducted in classes are presented in a summary form that details key features of lessons and specific use of interactive whiteboard and video conference technology.

\section{Observation sample: Year 11 Physics - 'Lifecycle of a lesson'}

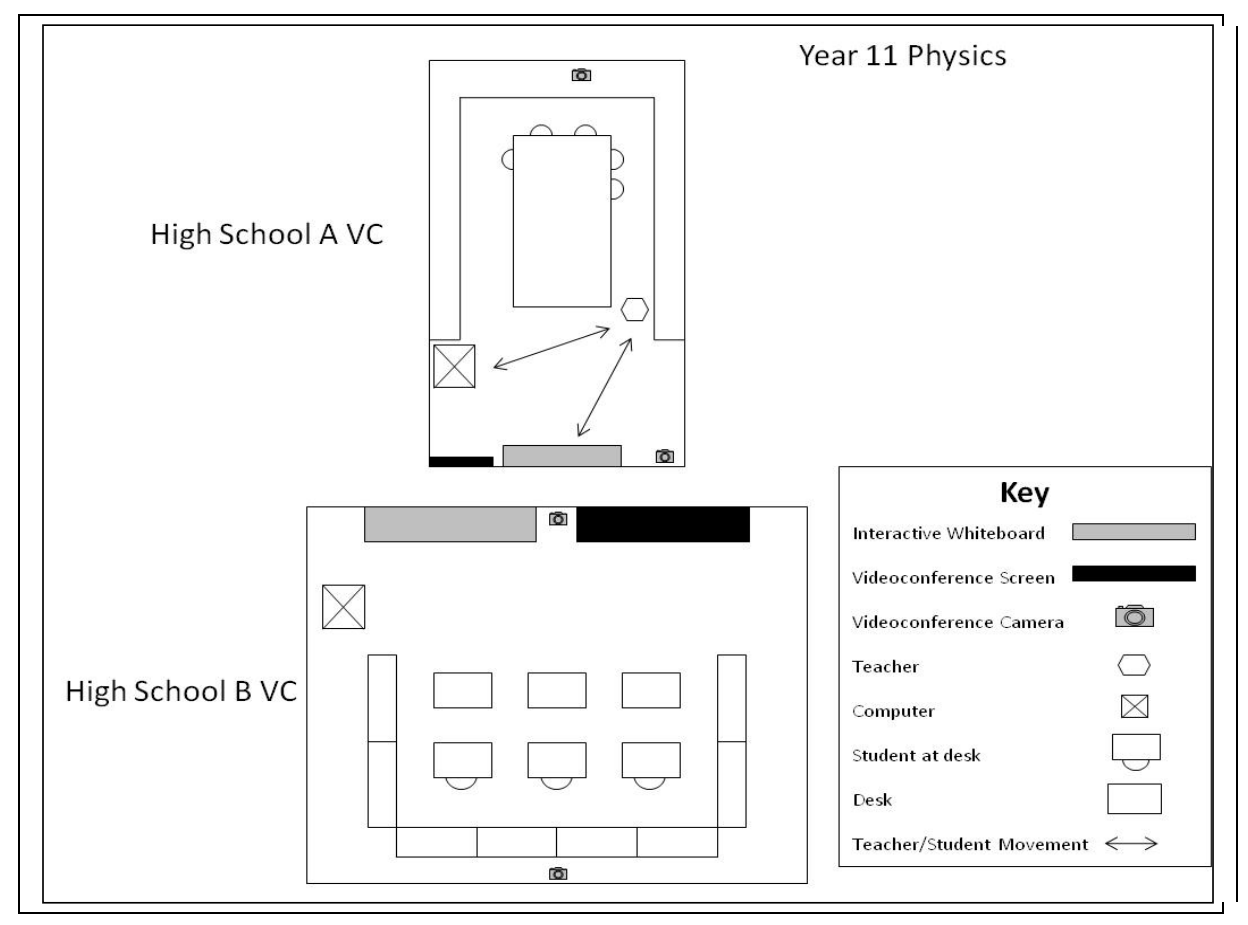

Figure 1: Year 11 physics connected classroom 
In this Physics lesson the teacher was in the 'connected classroom' at the High School A site with five students. Three students were in the room at the High School B site (Figure 1). The lesson was observed from the 'receiving' site at High School B. The observation focused on the range of activities that took place and how these activities enabled connections across the two sites.

Upon entering the room at High School B students went through the routines of technology set up and welcomes. It was clear that the students were familiar with the available technology - they ensured the data projector and microphone were on, the camera was focused, and the interactive whiteboard was connected.

The topic for this lesson was the lifecycle of stars. The lesson began with a recapitulation of material considered in the previous lesson. This led the class to build an interactive whiteboard chart showing the lifecycle of a star (see Figure 2). Using a pre-existing graphic the class completed the chart showing a sequence of activity with discussion followed by the writing of explanatory notes.

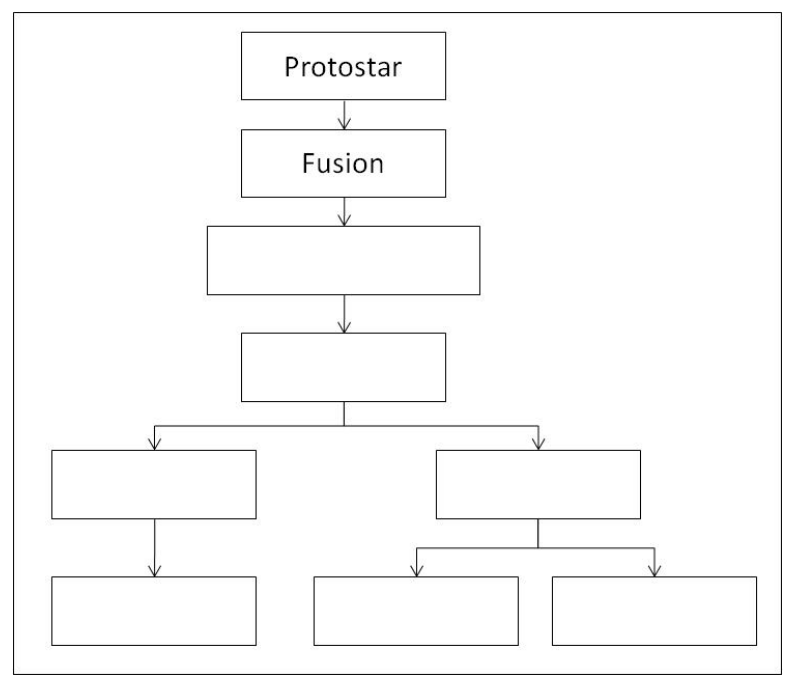

Figure 2: Star lifecycle - interactive whiteboard screen shot

In building the chart the teacher directed questions to students on the two sites, students from both sites asked questions, and the teacher provided additional explanation. During this activity the teacher was on the move - at the front of the room making notes on the interactive whiteboard, to the side of the room to face the camera and the students at High School B, turning to students in High School A, and returning to the interactive whiteboard again. Throughout, the teacher kept the conversational flow going and so when not directly in front of the camera students were able to hear her explaining ideas and asking questions as she was writing on the interactive whiteboard. Students wrote notes in their workbooks during this activity.

Following this activity the teacher used a five point star graphic as a tool for students to summarise key terms. Students at High School A wrote on the interactive whiteboard while students from High School C contributed ideas. 
The next topic focused on luminosity and brightness. Slides on the interactive whiteboard contained graphics and words. The teacher circled concepts to highlight the verbal explanation. A couple of jokes were shared across sites and within sites.

In the final part of the session the teacher showed a DVD that illustrated the lifecycle of a star and the associated physics. The video was played through the computer in the lab in High School A to both sites via the interactive whiteboard screen.

What was of note in this lesson was the sophistication of the interactive whiteboard slides/resources. The use of graphics, colour, and text to represent key ideas provided powerful visual cues and served to complement the teacher talk. Also, the teacher in this class deliberately moved and positioned herself in the room so that students could see her on the screen as well as attend to the material presented on the interactive whiteboard.

\section{Classroom observation summary}

The observations conducted in four of the classrooms have been summarised in Table 1 with the goal of identifying teaching practices related to the use of the IWB and the video conference technology. The table provides details of the year level and topic, the lesson structure and distinctive features of IWB use.

The detail in Table 1, coupled with the strategies identified in focus group discussions, was distilled in order to identify key components of practice in the $\mathrm{e}^{2}$ classes. The observational data and associated discussion revealed important and common aspects of the in-class strategies employed by teachers in the connected classrooms. The focus group discussions also revealed that there are critical components to the teaching practice that occur outside of the immediacy of the connected classroom. These critical components have been distilled in relation to the 'how' of strategies for working in connected classrooms. The focus group discussions importantly revealed why teachers were willing to work in these environments and this provides a critical rationale for using the available technology.

\section{The 'how' of $\mathrm{e}^{2}$ connected classes - strategies and practices}

The observational data, the production of the vignettes and the focus group interviews provided teachers and researchers with an opportunity to identify those features central to teaching practice in a video conference environment. In this section of the paper we return to the research questions to identify the pedagogic strategies that teachers have developed in the connected classroom environment, the ways in which these strategies are different from a traditional classroom, and the enablers and constraints to learning in the connected classroom. We focus in particular on the uses of the interactive whiteboard to connect the classrooms.

Through the teachers' portrayals of practice it was clear that the 'connected classrooms' represent learning spaces that required new and modified sets of teaching and learning strategies. Below Table 1 are components of teaching practice that were noted as common in the $\mathrm{e}^{2}$ environments; these may serve as recommendations for practice elsewhere. 
Table 1: Classroom observation summary

\begin{tabular}{|c|c|c|}
\hline $\begin{array}{l}\text { Subject, year } \\
\text { level and topic }\end{array}$ & $\begin{array}{c}\text { Lesson } \\
\text { structure } \\
\end{array}$ & $\begin{array}{l}\text { Teaching practices related to use } \\
\text { of IWB and other technology }\end{array}$ \\
\hline $\begin{array}{l}\text { Year } 11 \text { Legal } \\
\text { studies. Lesson } \\
\text { content - } \\
\text { human rights. }\end{array}$ & $\begin{array}{l}\text { VC and IWB link between schools } \\
\text { established, social exchange. } \\
\text { Teacher presentation of information related } \\
\text { to student presentations - advice for } \\
\text { preparing and presenting to the class. } \\
\text { Consideration of case material related to } \\
\text { human rights on the interactive whiteboard. } \\
\text { Teacher led discussion. } \\
\text { Student note-taking. } \\
\text { Each activity approx. } 10 \text { minutes. }\end{array}$ & $\begin{array}{l}\text { All case notes presented on IWB. } \\
\text { Teacher used highlighter tool to } \\
\text { note particular features of case } \\
\text { material. } \\
\text { Teacher position in classroom so } \\
\text { that students at receiving end } \\
\text { could use both screens - to see } \\
\text { the teacher and the IWB. }\end{array}$ \\
\hline $\begin{array}{l}\text { Year 12 Legal } \\
\text { studies. Lesson } \\
\text { content - } \\
\text { workplace } \\
\text { legislation }\end{array}$ & $\begin{array}{l}\text { VC and IWB link established. } \\
\text { Year } 12 \text { exams looming so that focus was on } \\
\text { ensuring sound understanding of content. } \\
\text { Six lesson creation software slides used to } \\
\text { structure lesson and highlight content. } \\
\text { Each slide contained a key idea - the idea } \\
\text { was considered in class and then additional } \\
\text { notes were written onto the slide by either } \\
\text { the teacher or one of the students. }\end{array}$ & $\begin{array}{l}\text { All slides presented on IWB. Both } \\
\text { teacher and students were able to } \\
\text { add notes to the IWB across both } \\
\text { sites. } \\
\text { Teacher's talk and IWB notes } \\
\text { needed to complement one } \\
\text { another. } \\
\text { At one point the IWB connection } \\
\text { at the receiving end froze when } \\
\text { students from both sites were } \\
\text { writing. Teacher responded by } \\
\text { maintaining talk. }\end{array}$ \\
\hline $\begin{array}{l}\text { Year } 11 \\
\text { Geography - } \\
\text { Lesson content } \\
\text { - globalisation, } \\
\text { cultural } \\
\text { integration and } \\
\text { trans-national } \\
\text { corporations. }\end{array}$ & $\begin{array}{l}\text { VC and IWB connection established. } \\
\text { YouTube video of a popular singer played } \\
\text { through IWB to introduce lesson and } \\
\text { illustrate cultural integration. } \\
\text { Teacher exposition and question and answer } \\
\text { re cultural integration - PowerPoint slides } \\
\text { through IWB used to support this part of the } \\
\text { lesson. Students take notes. } \\
\text { Second part of the lesson focussed on trans- } \\
\text { national corporations. IWB slides with notes } \\
\text { and graphics used as a stimulus for } \\
\text { discussion. } \\
\text { Link to an Internet site through the IWB for } \\
\text { students to access information about } \\
\text { corporations. }\end{array}$ & $\begin{array}{l}\text { IWB used to bring visual focus to } \\
\text { the lesson and to provide access } \\
\text { to an array of resources. } \\
\text { Teacher's spoken comments } \\
\text { tightly integrated with the text } \\
\text { and graphics on the IWB. } \\
\text { The two sites used the IWB } \\
\text { independently. } \\
\text { Seats and desks arranged to } \\
\text { maximise teacher use of VC } \\
\text { camera and alignment with IWB. }\end{array}$ \\
\hline $\begin{array}{l}\text { Year } 11 \text { Physics. } \\
\text { Lesson content } \\
\text { - lifecycle of a } \\
\text { star }\end{array}$ & $\begin{array}{l}\text { VC and IWB link established. } \\
\text { Recapitulation of previous lesson. } \\
\text { Interactive whiteboard chart used to build } \\
\text { lifecycle of a star. Teacher led discussion to } \\
\text { build the sequence of star activity. } \\
\text { Student and teacher questions and answers - } \\
\text { students take notes in their book based on } \\
\text { the IWB chart and the discussion. } \\
\text { Whiteboard graphic to summarise key } \\
\text { terms. Students from one site write the notes } \\
\text { on the whiteboard. } \\
\text { IWB slides on luminosity and brightness of } \\
\text { stars. Teacher explanation and IWB } \\
\text { highlighter used to note key points. } \\
\text { DVD shown through the IWB. }\end{array}$ & $\begin{array}{l}\text { Integrated use of graphics, colour } \\
\text { and text for all IWB material. } \\
\text { Visual cues to complement } \\
\text { teacher talk. } \\
\text { Teacher movement to ensure that } \\
\text { students could see her through } \\
\text { the VC attend to material on the } \\
\text { IWB. }\end{array}$ \\
\hline
\end{tabular}




\section{State specific and core teaching strategies}

The following actions were noted in all lessons observed and confirmed by the teachers:

- A common start-up routine in which students take responsibility for connecting the classrooms, this includes turning on the screens, computers, etc.

- The use of the interactive whiteboard to bring focus to key parts of the lesson.

- The importance of teacher's voice and the link to the visual cues on the interactive whiteboard.

- The position of the teacher in the room so that the visual links of the teleconference complemented the visual cues on the interactive whiteboard.

- Tight lesson structure with a strong teacher leadership of at least three activities in each lesson.

Every lesson observed used the interactive whiteboard and teachers indicated that it was a commonly used tool in their lessons in the connected classrooms. The interactive whiteboard was used to provide the key visual resources for each lesson, be it in the form of notes for the class to write down; notes and diagrams for the class to construct; links to Internet sites; or a screen through which to play video material. While members of the class could see one another through the video conferencing tools, the interactive whiteboard provided the screen focus for the lesson and was complemented primarily by the voice of the teacher. In this respect the video conference screen was secondary to the interactive whiteboard screen.

\section{Requirement for detailed planning}

All teachers noted that considerable planning was required to work in these new environments. Being able to 'wing' a lesson was not an option in the 'connected classroom' environment because material needed to be ready and prepared for distribution across campuses via the interactive whiteboard. Planning was also important to structure the integration of technologies in the lesson, which is the complementary use of video conference and interactive whiteboard screens, and the interaction made possible between teachers and students through both the video conference and interactive whiteboard screen.

\section{Development of teaching strategies relevant to curriculum and environment}

A common and key feature of teachers' comments was their concern to develop and deploy teaching and learning strategies relevant to both the curriculum and the environment. While teachers employed many similar teaching strategies that built on general conceptions of good teaching, there was also the deliberate development of strategies specific to the content knowledge, and specific to the video conference context. For some teachers this involved the deployment of strategies and the application of resources that were central to their teaching in regular classrooms, but with a shift in focus for communication across sites. In this respect all teachers prepared electronic documents (either Microsoft Word or PowerPoint) that provided the foundation for notes for students. There was some variation in the ways in which teachers developed the visual component of resources. In the Legal Studies classes the focus was on written texts. In the Physics class the teacher deployed visual graphics in order to build images of the physical concept being studied and in order to provide an 
additional stimulus to learning. In the Geography lesson the teacher used Internet resources in order provide an illustration to begin the lesson and to enable access to web based resources. Teachers did note that the content driven focus of senior school studies did limit their flexibility with the technological tools and the amount of interactivity.

\section{Pay attention to the receiving end}

Teachers and students alike noted that being in the receiving classroom (i.e. without the physical presence of the teacher) had some limitations. One student noted that it was easy to 'zone out' when the teacher was not in the actual classroom. Other students indicated that being in the receiving classroom required them to be more independent and to work together as a group. That said, these students also acknowledged that they focused in a different way when the teacher was actually present in their classroom. While the interactive whiteboards offer some potential for student interactivity and joint building of ideas, this function was not often used in the classes observed. In one of the observed lessons students from each site wrote some notes on the interactive whiteboards, but this caused one interactive whiteboard to freeze and so stopped the potential for written interaction across both sites.

To enable all students to be able to work directly with a teacher, small group tutorial contact between teachers and students on each school site has been developed to complement the connected classrooms. Teachers travel to different school sites for these tutorials. The tutorials provide an important way of building relationships with students and checking and supporting students' understanding of the curriculum. The teachers also varied the sites for lesson delivery so that one group of students was not always in the 'receiving' classroom.

\section{Possibility for professional learning 'on the job'}

Teachers developed much of their new pedagogical knowledge through processes of experimentation and collaboration with colleagues. The knowledge required to work in these 'connected classrooms' has not been developed through attending workshops outside the school. Rather, through support and guidance provided by the $\mathrm{e}^{2}$ leadership team, and through their own reflections on practice, teachers have built new forms of pedagogical knowledge and created new learning environments. One of the teachers undertaking the observations noted how instructive it was to observe a lesson from the receiving end. He stated that it was the "best PD I have had". Another experienced teacher noted that the opportunity to work in a new environment had revitalised his teaching.

\section{Comparison with face to face classrooms}

There was agreement among the teachers that the connected classroom technology has limitations when compared to face to face teaching. There is not necessarily the same flexibility, the opportunities for more practical lessons, or the potential to build a strong sense of class community. However, it was also obvious through the discussions that teachers were prepared to experiment with the available technologies in order to maintain curriculum options for students in the schools and to create new conditions and strategies that would support high quality pedagogy. Moreover, as teachers became more familiar with the technology and the 'connected classroom' 
environments, they noted that when stepping back into a 'traditional' classroom they missed the affordances associated with the interactive technology. In fact the limitations of regular classrooms became apparent.

Assessment practices were restricted by the nature of the Year 11 and 12 curriculum requirements and so typically remained pen and paper based. Teachers indicated that greater use of the technology as part of the assessment processes was an area for further exploration. Teachers commented that the 'connected classroom' environment suited students who were able to work in relatively independent ways.

\section{The 'why' of the 'connected classroom' - commitment to teaching in the $\mathrm{e}^{2}$ program}

One of the most noticeable comments made by teachers in the focus groups interviews was their commitment to their work in the $\mathrm{e}^{2}$ environment. Teachers' commitment was obvious at a number of levels: to the subject/s that they were teaching; to the students with whom they were working; to the $\mathrm{e}^{2}$ concept and environments; and to the schools and their local communities and towns. The $\mathrm{e}^{2}$ program provides students in Year 11 and 12 with a broad array of curriculum options because it connects schools in rural communities. The provision of these curriculum options across school sites was crucial to teachers' commitment. Because of this commitment teachers were prepared to experiment with new approaches; build their skills associated with using interactive whiteboard and video conference technology; work through some of the pros and cons of the connected classrooms; and take time for the complex planning required to teach via a cross-campus video connection and interactive whiteboard. In this respect there was a strong purpose associated with the use of the interactive whiteboard, it was the visual key to the connections between the classrooms. The use of the interactive whiteboard was not an unnecessary addition to the classroom; rather it was a central communicative tool.

The commitment to the creation of new environments that support the learning opportunities for students in the region is central to 'the why' of pedagogy in the $\mathrm{e}^{2}$ program. The pedagogy of the $\mathrm{e}^{2}$ program is a deliberate response to factors associated with rural and regional location, i.e. small rural schools wanting to extend the curriculum options for their students beyond that which they can provide individually; and a cluster of diverse regional/rural schools wanting to develop complementary rather than competing programs for students. This commitment has underpinned the application of new technologies, particularly interactive whiteboard and video conference tools, and the development of pedagogical strategies specific to the $\mathrm{e}^{2}$ environments.

\section{Conclusion}

The rhetoric associated with the application of educational technology in schools has remained strong over the last decade. Each suite of new communication tools poses different pedagogical challenges and questions for teachers and researchers in relation to how and why the technology is used to support instruction. The research in this paper has sought to document the knowledge and practice developed by teachers when 'connecting classrooms'. It is important to note that through trial, error and reflection the teachers in $\mathrm{e}^{2}$ classrooms have developed a set of teaching strategies for working in these new learning environments. 
The research reported in this paper has revealed that teachers have developed some specific communication strategies to connect classrooms across school sites. What was of note in the 'connected classroom' with two screens was the importance of the visual cues provided by the interactive whiteboard alongside the aural cues provided typically by the teacher talking. The teachers used the interactive whiteboard in varying ways - in most cases it provided a vehicle for presenting written notes. Yet teachers also sought to extend the uses in order to build images and graphic representation of ideas, connect to the Internet and encourage students to write notes that could be shared across classrooms.

In the $\mathrm{e}^{2}$ context perhaps what is of greatest importance is the rationale underpinning the technology. In this case teachers were committed to working with the technology because it provided curriculum options for senior students in rural NSW schools. In this case, the engagement potential associated with the interactive whiteboard technology was most noticeable through the connection between classrooms and students on different school sites. Directions for research and practice that have emerged through this project include: the development of assessment tools that use the connected classroom technology; the preparation of professional learning materials that provide other teachers with guidelines for connecting classrooms across school sites; and more detailed analysis of student learning and achievement in connected classroom contexts.

\section{Acknowledgments}

The authors acknowledge and thank NSW DET personnel involved in the $\mathrm{e}^{2}$ program for their support for this research. In particular, the authors thank the $\mathrm{e}^{2}$ teachers who participated in this research. The research was supported by a Charles Sturt University Research Development Grant. The authors also thank Lisa McLean from CSU for her assistance with the production of this paper and Claire Britt for her contribution to the research training and collaboration days.

\section{References}

Deaney, R., Ruthven, K. \& Hennessy, S. (2006). Teachers' developing 'practical theories' of the contribution of information and communication technologies to subject teaching and learning: An analysis of cases from English secondary schools. British Journal of Educational Research, 32(3), 459-480.

Green, H. \& Hannon, C. (2007). Their space: Education for a digital foundation. London: Demos Foundation.

Hennessy, S., Deaney, R., Ruthven, K. \& Winterbottom, M. (2007). Pedagogical strategies for using the interactive whiteboard to foster learner participation in school science. Learning, Media and Technology, 22(3), 283-301.

Higgins, S. (2005). Embedding ICT in the literacy and numeracy strategies. Newcastle: University of Newcastle upon Tyne.

Hunter, J. (2007). Fresh equation: Quality digital resources + interactive whiteboards + collaborative tools = engaging pedagogy for the classroom. Learning, Media and Technology, 32(3), 245-260. 
Kennewell, S. (2006). Reflections on the interactive whiteboard phenomenon: A synthesis of research from the UK. In Proceedings of the Australian Association for Research in Education Conference, Melbourne. http:// www.aare.edu.au/06pap/ken06138.pdf

Kennewell, S. \& Higgins, S. (2007). Introduction. Learning, Media and Technology, 32(3), 207-212.

Martin, M. (2005). Seeing is believing: The role of video conferencing in distance learning. British Journal of Educational Technology, 36(3), 397-405.

Ministerial Council on Education and Employment Training and Youth Affairs (2005). Contemporary learning: Learning in an online world. Canberra: DEST. [verified 10 Jun 2010] http: / / www.mceetya.edu.au/verve/_resources/Contemp_Learning_Final.pdf

Ministerial Council on Education and Employment Training and Youth Affairs (2006). Report of the ICT in Schools Taskforce. Canberra: DEST.

Ministerial Council on Education and Employment Training and Youth Affairs (2008a). Melbourne Declaration on Educational Goals for Young Australians. [viewed 3 June 2010]. http: / / www.mceecdya.edu.au/verve/_resources/National_Declaration_on_the_Education al_Goals_for_Young_Australians.pdf

Ministerial Council on Education and Employment Training and Youth Affairs (2008b). Digital education - Making change happen. Canberra: DEEWR. [verified 10 Jun 2010] http: / / www.aictec.edu.au/aictec/webdav/site/standardssite/shared / Digital_EducationMaking_Change_Happen.pdf

Muir, K. (2004). Connecting communities with CTLCs. Sydney: The Smith Family.

New South Wales Government (2009). Connected classrooms program. https: / / www.det.nsw.edu.au/strat_direction/schools/ccp / [viewed 3 June 2010].

NSW Department of Education and Training (2003). Quality teaching in NSW public schools: A discussion paper. Ryde: Professional Support and Curriculum Directorate.

NSW Department of Education and Training (2007). Engaging pedagogy: Teachers in the field. Sydney: Centre for Learning Innovation.

Schuck, S. \& Kearney, M. (2006). Exploring pedagogy with interactive whiteboards: A case study of six schools. Sydney: UTS Press. [verified 10 Jun 2010; 8.2 MB] http:/ / www.eddev.uts.edu.au/teachered/research/iwbproject/pdfs/iwbreportweb.pdf

Jane Mitchell

Faculty of Education, Charles Sturt University

Panorama Drive, Bathurst 2795, Australia

Email: jmitchell@csu.edu.au

Jane Hunter

School of Education, University of Western Sydney, Bankstown Campus

Locked Bag 1797, Penrith South D.C. 1797 NSW, Australia

Email : j.hunter@uws.edu.au

Nicole Mockler

School of Education, University of Newcastle

PO Box 127, Ourimbah NSW 2258, Australia

Email: Nicole.Mockler@newcastle.edu.au 